Article

\title{
Surface-Controlled Conversion of Ammonia Borane from Boron Nitride
}

\author{
Tessui Nakagawa ${ }^{1, *}$, Hiroki Uesato ${ }^{2}$, Anthony K. Burrell ${ }^{3, *}$, Takayuki Ichikawa ${ }^{4}$, \\ Hiroki Miyaoka ${ }^{4}$, Benjamin L. Davis ${ }^{3}$ and Yoshitsugu Kojima ${ }^{4}$ \\ 1 Faculty of Science, University of the Ryukyus, 1 Senbaru, Nishihara-cho, Okinawa 903-0213, Japan \\ 2 Graduate School of Engineering and Science, University of the Ryukyus, 1 Senbaru, Nishihara-cho, \\ Okinawa 903-0213, Japan; h.u.revolutioner@gmail.com \\ 3 Materials Physics and Applications Division, Los Alamos National Laboratory, MS J514 Los Alamos \\ National Laboratory, Los Alamos, NM 87575, USA; bldavis@lanl.gov \\ 4 Institute for Advanced Materials Research, Hiroshima University, 1-3-1 Kagamiyama, \\ Higashi-Hiroshima 739-8530, Japan; tichi@hiroshima-u.ac.jp (T.I.); miyaoka@hiroshima-u.ac.jp (H.M.); \\ kojimay@hiroshima-u.ac.jp (Y.K.) \\ * Correspondence: tessui@sci.u-ryukyu.ac.jp (T.N.); Anthony.Burrell@nrel.gov (A.K.B.); \\ Tel.: +81-98-895-8535 (T.N.)
}

Received: 1 October 2020; Accepted: 20 October 2020; Published: 23 October 2020

check for updates

\begin{abstract}
One-pot regeneration", which is simple regneneration method of ammonia borane (AB) using hydrazine and liquid ammonia, enables conversion of $\mathrm{AB}$ from hexagonal boron nitride (h-BN) after milling hydrogenation. Solution ${ }^{11} \mathrm{~B}-\mathrm{NMR}$ revealed the presence of $\mathrm{AB}$ after $\mathrm{NH}_{3} / \mathrm{N}_{2} \mathrm{H}_{4}$ treatment of milled h-BN $\left(\mathrm{BNH}_{x}\right)$ although the yield of $\mathrm{AB}$ was less than $5 \%$. The conversion mechanism was clarified as $\mathrm{B}-\mathrm{H}$ bonds on the $\mathrm{h}-\mathrm{BN}$ surface created by ball-milling under hydrogen pressure have an ability to form $\mathrm{AB}$, which was confirmed by Thermogravimetry-Residual Gas Analysis (TG-RGA) and Infrared (IR) analysis. The reaction routes are also the same as regeneration route of polyborazylene because intermediates of $\mathrm{AB}$ such as $\left(\mathrm{B}\left(\mathrm{NH}_{2}\right)_{3}\right.$ and hydrazine borane were found by solution ${ }^{11} \mathrm{~B}-\mathrm{NMR}$ after soaking $\mathrm{BNH}_{x}$ in liquid $\mathrm{NH}_{3}$ and hydrazine, respectively. Because of the fact that all reactions proceed on the h-BN surface and no reaction proceeds when neat $\mathrm{h}-\mathrm{BN}$ is treated, breaking of $\mathrm{B}_{3} \mathrm{~N}_{3}$ ring structure and then creation of $\mathrm{B}-\mathrm{H}$ bond is the key issue to increase conversion yield of $\mathrm{AB}$.
\end{abstract}

Keywords: hydrogen storage; ammonia borane; boron nitride; milling; nuclear magnetic resonance; hydrogenation

\section{Introduction}

In the future, a major hurdle of realizing carbon constraining world is storage and transportation of energy. While there are many potential green sources of electrical energy generation (e.g., solar and wind), both the intermittency and remoteness of these sources will severely limit their practical application at large scale [1]. Storage of the electric energy produced by intermittent sources would allow a leveling of the supply that should enable the "green-grid". There are many possible ways to store the energy, but chemical bonds represent perhaps the cheapest option. Hydrogen generated from electrolysis suffers from several drawbacks: it is a gas and therefore requires either large volumes or high pressures to store [2]. Similar issues arise in the application of hydrogen as a fuel in automotive applications. Although the commercial hydrogen fuel cell vehicle can store $70 \mathrm{MPa}$ of hydrogen with about 5.5 mass \% including tank, improvement of hydrogen storage technology with higher hydrogen density (U.S. DOE ultimate target: 6.5 mass $\%$ of system) is required [2]. The promising way to store hydrogen with high density is hydrogen storage material; therefore, many different hydrogen 
storage media have been considered to improve their gravimetric and volumetric density of usable hydrogen [3]. One of the recent high profile candidates is ammonia borane $\left(\mathrm{AB} ; \mathrm{NH}_{3} \mathrm{BH}_{3}\right)$ because of its 19.6 mass\% of hydrogen capacity and moderate initial dehydrogenation temperature $\left(\sim 110{ }^{\circ} \mathrm{C}\right)[4]$. $\mathrm{AB}$ desorbs hydrogen over a wide range of temperatures in three idealized steps, as follows [5]:

$$
\begin{gathered}
\mathrm{NH}_{3} \mathrm{BH}_{3} \rightarrow{ }^{\prime} \mathrm{NH}_{2} \mathrm{BH}_{2}{ }^{\prime \prime}+\mathrm{H}_{2}, 6.5 \text { mass } \%<114{ }^{\circ} \mathrm{C} \\
\text { "NHBH" }+2 \mathrm{H}_{2}, 13.1 \text { mass } \%<200{ }^{\circ} \mathrm{C} \\
\mathrm{BN}+3 \mathrm{H}_{2}, 19.6 \text { mass } \%>400{ }^{\circ} \mathrm{C}
\end{gathered}
$$

In reality, the decomposition pathway of $\mathrm{AB}$ is more complicated and the " $\mathrm{NH}_{2} \mathrm{BH}_{2}$ " and " $\mathrm{NHBH}$ " species are better represented as polymers. While, on the face of it, AB looks like an excellent material for hydrogen storage, there are several issues to be overcome before practical use could be a reality [6]. Issues with the kinetics of hydrogen release have been well-examined by many research groups using a wide range of approaches such as catalysts [7], Lewis and Brønsted acids [8], metal hydrides [9], proton sponge activation [10], ionic liquids [11], confinements [12], and metal-substitution as metal amidoboranes [13]. However, the major limitation of $\mathrm{AB}$ has always been the exothermic nature of hydrogen release although this nature has advantages from a technological point of view, in that no extra energy is required to obtain hydrogen from $\mathrm{AB}$. This nature prohibits the direct rehydrogenation of the dehydrogenated material form back to $\mathrm{AB}$ by simple pressurizing hydrogen gas. Only chemical recycle route (regeneration) is possible to recharge hydrogen into dehydrogenated $\mathrm{AB}$. The dehydrogenated material, or "spent fuel" as it is often called, is a complex mixture of polymeric $\left\{\mathrm{BNH}_{x}\right\}_{n} \mathrm{species}$ (polyborazylene: $\mathrm{PB}$ ), generally containing hydrogen. $\mathrm{PB}$ has linear or $\mathrm{B}_{2} \mathrm{~N}_{3}$ ring structures with many degrees of polymerization, which depends on amount and condition of released hydrogen. The full release of hydrogen from $A B$, which is the ceramic boron nitride (h-BN), is also spent fuel, but h-BN was considered too robust to be ever converted back to $A B$ due to quite strong bonds in $B_{3} N_{3}$ ring structure. Therefore, less than 2.5 equivalents of hydrogen released from $A B$ would be favorable for regeneration, which means hydrogen in the $\left\{\mathrm{BNH}_{x}\right\}_{n}$ species would facilitate the chemical reformation of $\mathrm{AB}$. The proto-typical spent fuel, which is ring-structured PB made from borazine $\left(\mathrm{B}_{3} \mathrm{~N}_{3} \mathrm{H}_{6}\right)$ [14], has been successfully converted back to $\mathrm{AB}$ by using benzenethiol [15] as a digesting agent followed by tin hydrides [16] for hydrogen transfer. Moreover, we eventually established a quite simple one-pot $A B$ regeneration technique from $\mathrm{PB}$ using hydrazine $(\mathrm{Hz})$ in liquid ammonia (liq. $\mathrm{NH}_{3}$ ) as the hydrogen transfer reagent [17]. This "one-pot regeneration" rapidly proceeds within 24 h via two reaction routes: hydrazine reacts with $\mathrm{PB}$ to form hydrazine borane $\left(\mathrm{N}_{2} \mathrm{H}_{4} \mathrm{BH}_{3}\right)$ and then $\mathrm{AB}$ forms by the ligand exchange from $\mathrm{N}_{2} \mathrm{H}_{4}$ to $\mathrm{NH}_{3}$ [17]; $\mathrm{HB}\left(\mathrm{NH}_{2}\right)_{2}$ forms by the reaction between $\mathrm{PB}$ and ammonia in the liquid ammonia and then $\mathrm{AB}$ and $\mathrm{B}\left(\mathrm{NH}_{2}\right)_{3}$ form by the disproportionation of $\mathrm{HB}\left(\mathrm{NH}_{2}\right)_{2}$ [18]. The theoretical approach indicates that only B-H bond can react with $\mathrm{NH}_{3}$ and $\mathrm{N}_{2} \mathrm{H}_{4}[17,18]$, which means that $\mathrm{B}-\mathrm{H}$ bonding is mandatory for regeneration.

While some reports of $\mathrm{AB}$ regeneration [19-21] and lithium amidoborane $\left(\mathrm{LiNH}_{2} \mathrm{BH}_{3}\right)$ [22] have been published, there is still a great challenge remaining which is full-regeneration of $\mathrm{AB}$ from hexagonal boron nitride (h-BN). Based upon simple thermodynamic argument, $\mathrm{h}-\mathrm{BN}$ is too far downhill to be considered as a precursor for $\mathrm{AB}$ (endothermic reaction, $\Delta H=215.4 \mathrm{~kJ} / \mathrm{mol}$ ) due to full-dehydrogenated state of $\mathrm{AB}[23,24]$. Another fact, that h-BN has no B-H bonding, is also a big issue for regeneration. Therefore, direct hydrogenation of bulk h-BN to AB might be difficult to proceed. Graphite, which has similar structure to h-BN, is also difficult to hydrogenate directly at room temperature but ball-milling under hydrogen pressure, a strong hydrogenation tool, realizes hydrogenation of carbon at room temperature (RT) [25]. Even ball-milling hydrogenation method has been employed, no AB formed but only surface on h-BN was hydrogenated taking the form of " $\mathrm{BNH}_{x}$ ", which still has many $\mathrm{B}_{3} \mathrm{~N}_{3}$ rings $(h \mathrm{klm}=0002)$ supported by X-ray diffraction (XRD) [26]. The hydrogenation of h-BN during the ball milling process relies upon the formation of defects at the surface of h-BN, which is an apparently thermodynamic favorable process. Although $\mathrm{BNH}_{x}$ is smaller hydrogen coordination $(\mathrm{x}<0.5)$ than $\mathrm{PB}$ 
$(x=1.0)$ and has a similar structure to that of PB (Figure 1), the infrared (IR) spectrum of BNH showed both B-H and N-H stretching peaks with a structure similar to polyaminoborane (PAB; $\left.\left\{\mathrm{BH}_{2} \mathrm{NH}_{2}\right\}_{n}\right)$. Therefore, $\mathrm{BNH}_{x}$ is different from $\mathrm{PAB}$ in terms of $\mathrm{BH}_{2}$ species and number of $\mathrm{B}_{3} \mathrm{~N}_{3}$ ring structure. Now activated $\mathrm{BNH}_{x}$ is no longer as thermodynamically stable as h-BN and direct chemical conversion to $\mathrm{AB}$ using $\mathrm{N}_{2} \mathrm{H}_{4} / \mathrm{NH}_{3}$ is possible. Hence, the purpose in this study is to transform back to $\mathrm{AB}$ upon $\mathrm{N}_{2} \mathrm{H}_{4} / \mathrm{NH}_{3}$ treatment from B-H bonds in milling hydrogenated h-BN. We also investigated the reaction mechanism of this transformation including the reaction route.

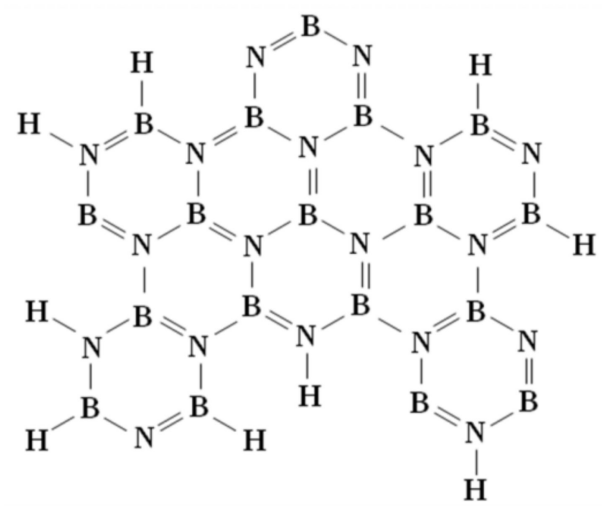

Figure 1. Structures of $\mathrm{BNH}_{x}$.

\section{Materials and Methods}

The starting material, h-BN nanopowder ( $<150 \mathrm{~nm}, 99 \%$, Aldrich Co. Ltd.) was used as received or after dried at $200{ }^{\circ} \mathrm{C}$ for $8 \mathrm{~h}$ under vacuum condition. $\mathrm{BNH}_{x}$ and $\mathrm{BN}-\mathrm{NH}_{x}(\mathrm{~N}-\mathrm{H}$ bonding coated h-BN) were synthesized by using the ball milling method under $1 \mathrm{MPa}$ of $\mathrm{H}_{2}$ or $0.8 \mathrm{MPa}$ of $\mathrm{NH}_{3}$ at RT for $80 \mathrm{~h}$ using vibration milling (SEIWA GIKEN Co. Ltd., RM-10) as the previous report [26]. In a typical reaction, $100 \mathrm{mg}$ of each sample (neat h-BN, $\mathrm{BNH}_{x}$, and $\mathrm{BN}-\mathrm{NH}_{x}$ ) was placed into stainless steel vessel (about $50 \mathrm{~mL}$ ) and cooled down to $-78{ }^{\circ} \mathrm{C}$ using a dry ice/ethanol mixture. Then $\mathrm{NH}_{3}$ was condensed into the container. After the addition of about $30 \mathrm{~mL}$ of liquid $\mathrm{NH}_{3}, 200 \mu \mathrm{L}$ of anhydrous hydrazine (98\%, Aldrich Co. Ltd.) was added. The reaction vessel was then sealed and heated at $40{ }^{\circ} \mathrm{C}$ for 1 week. These vessels were opened under atmospheric pressure containing condensed $\mathrm{NH}_{3}$ by cooling in liquid nitrogen before opening to prevent blowing up sample in the container. After warming up and the evaporation of $\mathrm{NH}_{3}$ under atmospheric pressure for $5 \mathrm{~h}$, residual $\mathrm{NH}_{3}$ and $\mathrm{N}_{2} \mathrm{H}_{4}$ were completely removed under dynamic vacuum maintained for $5 \mathrm{~h}$. All procedures were carried out without exposing air.

${ }^{11} \mathrm{~B}$ and ${ }^{1} \mathrm{H}$ solution nuclear magnetic resonance (NMR: Bruker, AVANCE 300, 96.29 MHz for ${ }^{11} \mathrm{~B}$ and $300.13 \mathrm{MHz}$ for ${ }^{1} \mathrm{H}$ ) of $\mathrm{BNH}_{x}$ and $\mathrm{N}_{2} \mathrm{H}_{4} / \mathrm{NH}_{3}$ treated samples were performed at room temperature using $\mathrm{d} 8 \mathrm{-THF}$ as the solvent. Samples for NMR were prepared by filtering by THF (about $50 \mathrm{~mL}$ ) then dynamic evacuation of filtered solution. External calibration of ${ }^{11} \mathrm{~B}$ NMR was performed using $\mathrm{BF}_{3}$-etherate standard $(0.0 \mathrm{ppm})$. We also measured ${ }^{11} \mathrm{~B}$ solution NMR (Bruker, AVANCE $400,128.38 \mathrm{MHz})$ of $\mathrm{BNH}_{x}$ after soaking in each solvent $\left(\mathrm{NH}_{3}\right.$ and $\left.\mathrm{N}_{2} \mathrm{H}_{4}\right)$ at $\mathrm{RT}$ for $24 \mathrm{~h}$ in order to confirm intermediates.

Thermogravimetric analysis (TGA) of $\mathrm{BNH}_{x}$ after the $\mathrm{N}_{2} \mathrm{H}_{4} / \mathrm{NH}_{3}$ treatment (whole sample including soluble and insoluble species) was performed by LABSYS evo (SETARAM). At the same time, gas analyses were performed by residual gas analyzer (RGA: INFICON, Transpector ${ }^{\circledR}$ CPM)

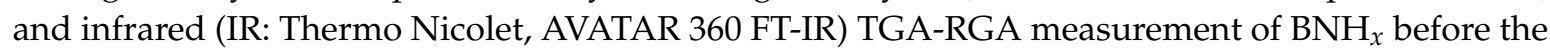
treatment and residual (after removal of $\mathrm{AB}$ ) treated $\mathrm{BNH}_{x}$ was simultaneously performed by TG 8120 (Rigaku) coupled with M-QA200TS (Canon Anelva Corporation). Both measurements were performed with a scanning rate of $10{ }^{\circ} \mathrm{C} / \mathrm{min}$. Powder X-ray diffraction (XRD) measurements were operated by RINT-2100 (Rigaku, $\mathrm{Cu} \mathrm{K} \alpha$ radiation) for $\mathrm{BNH}_{x}$ and $\mathrm{D} 8$ Discover (Bruker, $\mathrm{Cu} \mathrm{K} \alpha$ radiation) for 
$\mathrm{N}_{2} \mathrm{H}_{4} / \mathrm{NH}_{3}$ treated $\mathrm{BNH}_{x}$. All procedures have been performed without exposing the samples to air by handling in the Ar-filled glovebox except the TGA-RGA-IR measurement of $\mathrm{BNH}_{x}$ after the treatment, where the exposure time was minimized $(<10 \mathrm{sec})$.

\section{Results and Discussion}

The regeneration of $\mathrm{AB}$ is most simply followed by ${ }^{11} \mathrm{~B}$ solution NMR. The reaction of neat $\mathrm{h}-\mathrm{BN}$ with $\mathrm{N}_{2} \mathrm{H}_{4} / \mathrm{NH}_{3}$ showed no evidence of the formation of $\mathrm{AB}$ or any other molecular species even after prolonged time (Figure $\mathrm{S} 1 \mathrm{a}$ in supplementary materials). Extraction of $\mathrm{BNH}_{x}$, hydrogenated h-BN by ball milling, with THF yielded no observable B-H species in solution (Figure 2a). In contrast, when $\mathrm{BNH}_{x}$ was treated with $\mathrm{N}_{2} \mathrm{H}_{4} / \mathrm{NH}_{3}$ for 1 week, a soluble $\mathrm{BH}_{3}$ containing species ( $-20.4 \mathrm{ppm}$, $J_{\mathrm{B}, \mathrm{H}}=94 \mathrm{~Hz}$ ) is presented (Figure $2 \mathrm{~b}$ ). This resonance is identified as $\mathrm{AB}$ by comparison with commercial $\mathrm{AB}$. In addition, mixture of this soluble species and the commercial $\mathrm{AB}$ showed single peak in ${ }^{11} \mathrm{~B}$ NMR spectrum (Figure $\left.\mathrm{S} 1 \mathrm{~b}\right)$. Although hydrazine borane $(\mathrm{HzB})$ can be produced as an intermediate compound or by the reaction between $\mathrm{AB}$ and $\mathrm{N}_{2} \mathrm{H}_{4}$, in liquid $\mathrm{NH}_{3}$ all of $\mathrm{HzB}$ can be converted to $\mathrm{AB}$ by metathesis (Figure $2 \mathrm{~b}$ ). The ${ }^{1} \mathrm{H}$ NMR spectrum of this product also shows the presence of resonances identified as triplet $\mathrm{NH}_{3}$ species in $\mathrm{AB}$ at $4 \mathrm{ppm}$ (Figure $\mathrm{S} 2$ ).

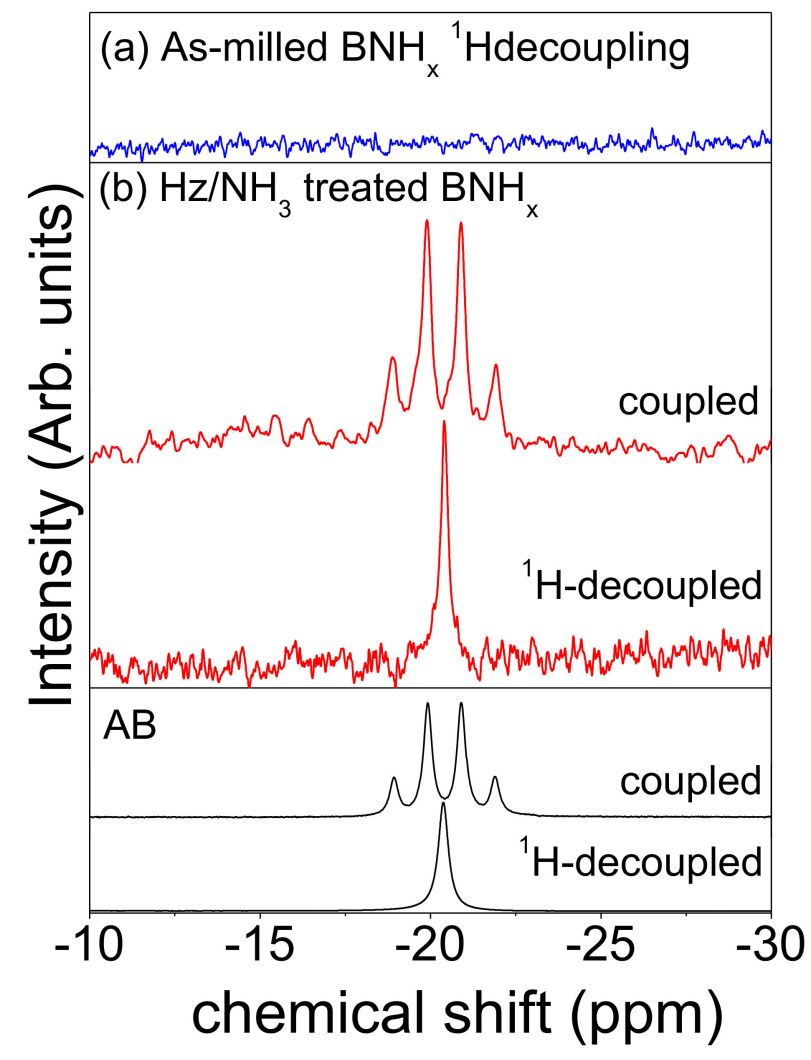

Figure 2. ${ }^{11} \mathrm{~B}$ solution NMR spectra of (a) as-milled $\mathrm{BNH}_{x}$ with ${ }^{1} \mathrm{H}$-decoupled and (b) $\mathrm{BNH}_{x}$ after $\mathrm{N}_{2} \mathrm{H}_{4} / \mathrm{NH}_{3}$ treatment with ${ }^{1} \mathrm{H}$-coupled and decoupled. Profiles of ammonia borane (AB) as a reference are also shown.

Unfortunately, the yield of $A B$ is not significant overall being less than $5 \%$ based upon the mass of treated $\mathrm{BNH}_{x}$. It is important to reveal the mechanism of this reaction in order to improve $\mathrm{AB}$ yield using this method. It is likely that only the surface of h-BN is hydrogenated during the ball milling process and only this surface is susceptible to be attacked by $\mathrm{NH}_{3}$ and $\mathrm{N}_{2} \mathrm{H}_{4}$. We have reported that $\mathrm{BNH}_{x}$, hydrogenated h-BN by ball milling, is still dominated by the hexagonal $\mathrm{N}_{3} \mathrm{~B}_{3}$ ring structure of h-BN, even after $80 \mathrm{~h}$ milling [26]. Indeed, our X-ray diffraction analysis (XRD) of $\mathrm{BNH}_{x}$ and the product after $\mathrm{N}_{2} \mathrm{H}_{4} / \mathrm{NH}_{3}$ treatment have diffraction peaks corresponding to h-BN ring structure 
( $h k l m=0002$, Figure $\mathrm{S} 3$ ). $\mathrm{BN}-\mathrm{NH}_{x}$, which is milled h-BN under ammonia pressure for $80 \mathrm{~h}$ [22], has not been shown in our hands to generate $\mathrm{AB}$ by the $\mathrm{Hz} / \mathrm{NH}_{3}$ treatment (Figure S1c), which is the same as the failure of neat h-BN to show any reaction with $\mathrm{N}_{2} \mathrm{H}_{4} / \mathrm{NH}_{3}$. This is part of the evidence that presence of the B-H bonds is critical to this reaction as confirmed. Moreover, the calculation results in the previous report support that $\mathrm{B}-\mathrm{H}$ bonds are only reactive with $\mathrm{NH}_{3}$ and $\mathrm{N}_{2} \mathrm{H}_{4}$ but not N-H bonds [17,18]. TG-RGA-IR analysis could support this speculation. RGA profile of $\mathrm{BNH}_{x}$ shows wide temperature range of hydrogen (and small amount of $\mathrm{N}_{2}$ and $\mathrm{NH}_{3}$ ) release (Figure 3a). On the other hand, residue $\left(\mathrm{N}_{2} \mathrm{H}_{4} / \mathrm{NH}_{3}\right.$ treated $\mathrm{BNH}_{x}$ after removal of $\mathrm{AB}$ ) desorbed mainly $\mathrm{NH}_{3}$ (and small amount of $\mathrm{N}_{2}$ and $\mathrm{H}_{2}$ ) below $500{ }^{\circ} \mathrm{C}$ (Figure $3 \mathrm{~b}$ ), which is similar to that of $\mathrm{BN}^{-\mathrm{NH}_{x}}$ denoted in Figure 3c. This phenomenon indicates that weak B-H bond in $\mathrm{BNH}_{x}$ was substituted from $\mathrm{NH}_{3}$ and $\mathrm{N}_{2} \mathrm{H}_{4}$ during treatment. Increase of $\mathrm{BNH}_{x}$ mass after the treatment (100 to $170 \mathrm{mg}$ ) can be this evidence. Additional evidence has been found in IR results because the residue has weaker B-H (about $2500 \mathrm{~cm}^{-1}$ ) and stronger $\mathrm{N}-\mathrm{H}$ peaks (about $3500 \mathrm{~cm}^{-1}$ ) than these $\mathrm{BNH}_{x}$ peaks (Figure S4). Overall untreated $\mathrm{BNH}_{x}$ loses about 2.5 mass $\%$ up to $900{ }^{\circ} \mathrm{C}$ whereas the residue loses 11.5 mass $\%$ mostly due to $\mathrm{NH}_{3}$ desorption. This is also evidence of substitution from B-H to N-H bonds.

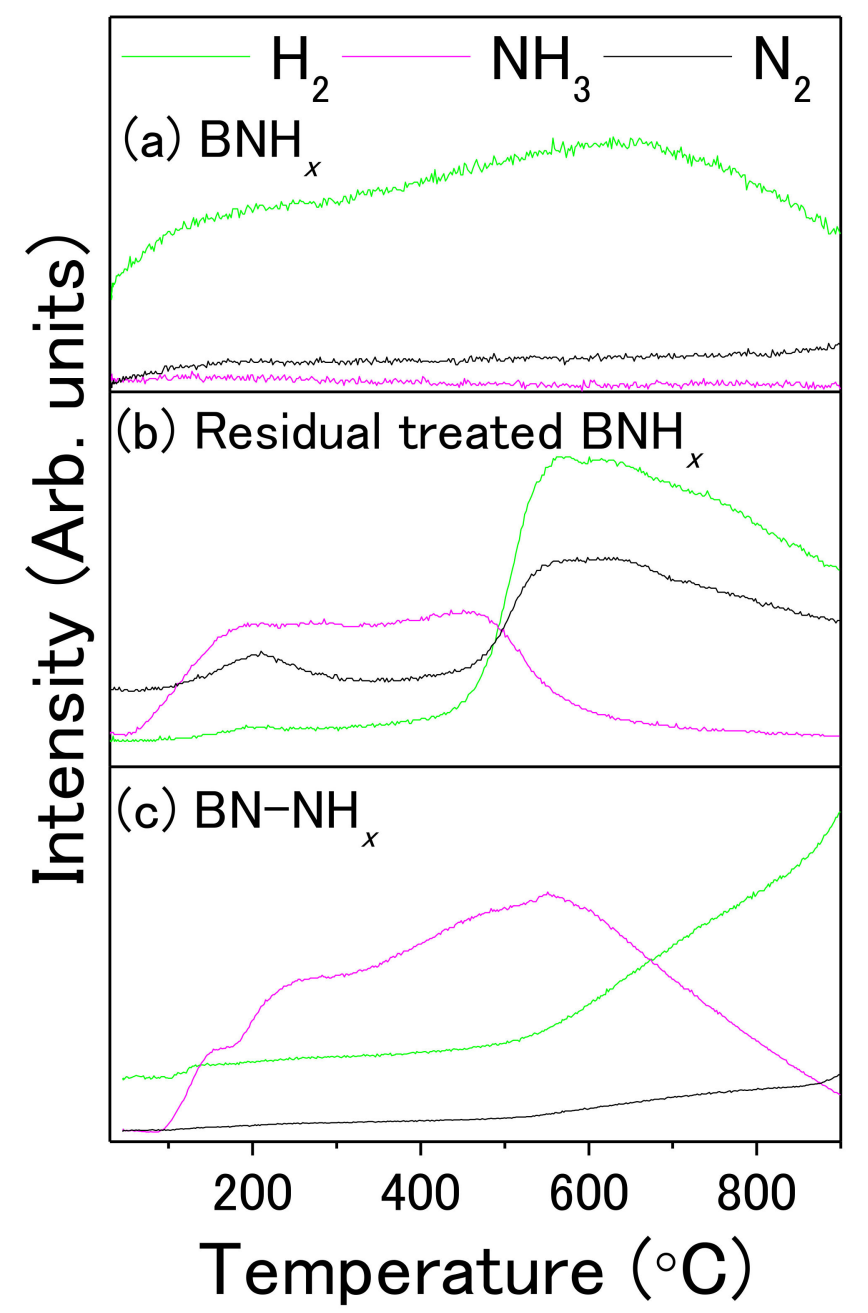

Figure 3. TG-RGA profiles of (a) $\mathrm{BNH}_{x}$, (b) residue of $\mathrm{N}_{2} \mathrm{H}_{4} / \mathrm{NH}_{3}$ treated $\mathrm{BNH}_{x}$, and (c) $\mathrm{BN}-\mathrm{NH}_{x}$.

The reaction path is also an important issue to be clarified for improvement of this method. As mentioned, the intermediate of $\mathrm{N}_{2} \mathrm{H}_{4}$ route is $\mathrm{N}_{2} \mathrm{H}_{4} \mathrm{BH}_{3}$, while the intermediates of $\mathrm{NH}_{3}$ route are $\mathrm{HB}\left(\mathrm{NH}_{2}\right)_{2}$ and $\mathrm{B}\left(\mathrm{NH}_{2}\right)_{3}$ (decomposition product of $\left.\mathrm{HB}\left(\mathrm{NH}_{2}\right)_{2}\right)$. The simple way to confirm their presence is $\mathrm{NMR}$ measurement after soaking $\mathrm{BNH}_{x}$ in liquid $\mathrm{NH}_{3}$ or $\mathrm{N}_{2} \mathrm{H}_{4} \cdot{ }^{1} \mathrm{H}$-decoupled ${ }^{11} \mathrm{~B}$ solution 
NMR spectra (solvent: THF) after soaking in both $\mathrm{N}_{2} \mathrm{H}_{4}$ and liquid $\mathrm{NH}_{3}$ had a weak peak at $-20.2 \mathrm{ppm}$ (Figure 4a) and a strong peak at $26.5 \mathrm{ppm}$ with a small shoulder (Figure $4 \mathrm{~b}$ ), respectively. Although the signals in the coupled spectrum of $\mathrm{N}_{2} \mathrm{H}_{4}$-soaked sample were too weak to identify, this peak position is close to $\mathrm{N}_{2} \mathrm{H}_{4} \mathrm{BH}_{3}$. The peak in the NMR spectrum in liquid $\mathrm{NH}_{3}$-soaked sample locates almost the same as $\mathrm{B}\left(\mathrm{NH}_{2}\right)_{3}$. Other peak was not observed in both spectra. Thus, regeneration route of $\mathrm{BNH}_{x}$ could be the same as PB regeneration route as we reported.

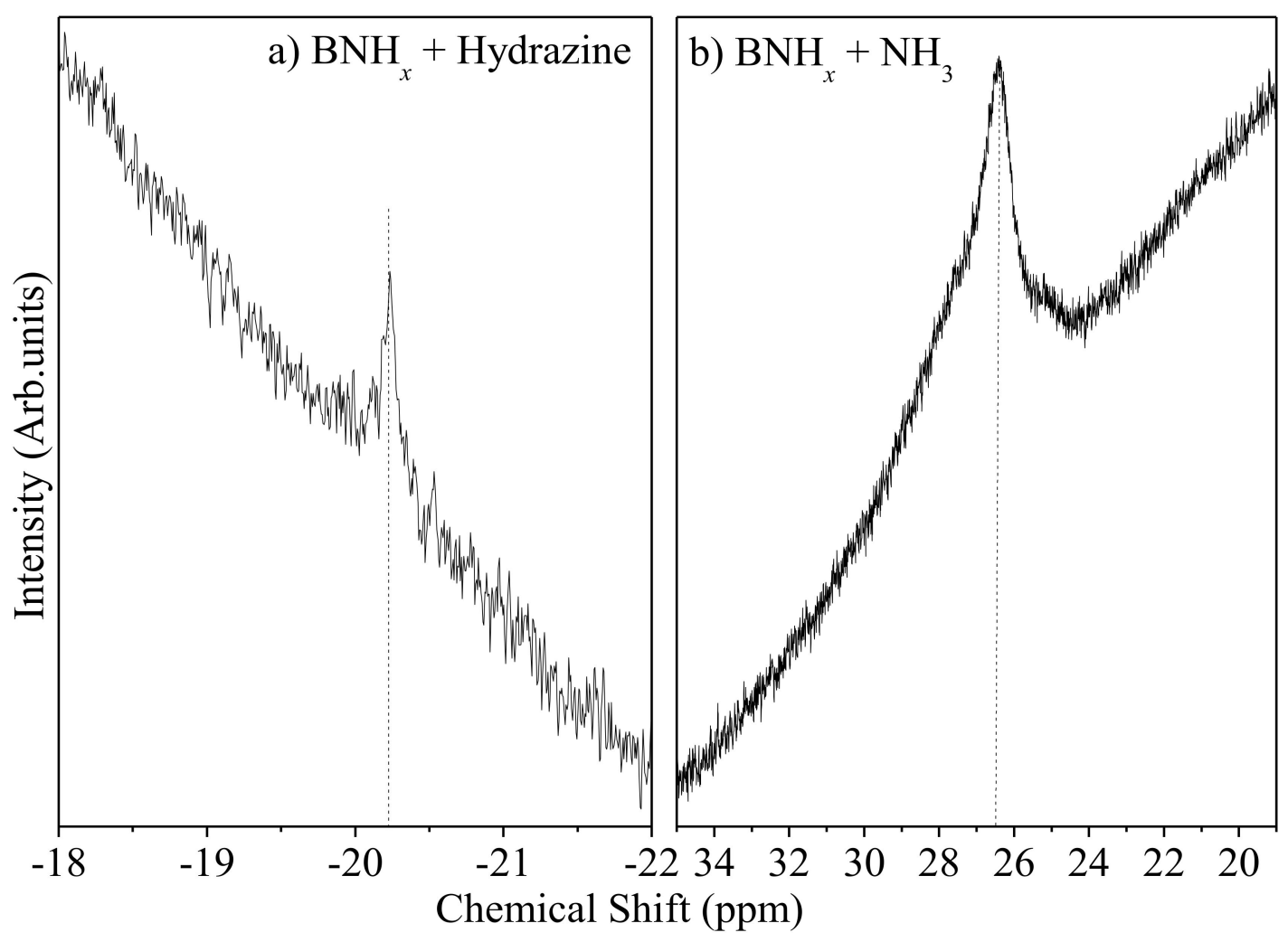

Figure 4. ${ }^{11} \mathrm{~B}\left\{{ }^{1} \mathrm{H}\right\}$ solution $\mathrm{NMR}$ spectra of $\mathrm{BNH}_{x}$, after soaking in $(\mathbf{a}) \mathrm{N}_{2} \mathrm{H}_{4}$ and (b) liquid $\mathrm{NH}_{3}$ (solvent: $\mathrm{THF})$.

When we consider these observations, a probable reaction mechanism for the formation of the $\mathrm{AB}$ from h-BN can be envisioned. Firstly, all of the reactions, from the ball milling through to the reactions with $\mathrm{N}_{2} \mathrm{H}_{4} / \mathrm{NH}_{3}$, only occur at the $\mathrm{BN}$ surface. Previous calculations indicate that only the B-H bonds in $\left(\mathrm{BNH}_{x}\right)_{n}$ have an ability to form $\mathrm{AB}$ on reaction with $\mathrm{N}_{2} \mathrm{H}_{4}$ and $\mathrm{NH}_{3}$, while the $\mathrm{B}_{3} \mathrm{~N}_{3}$ ring structure is unaffected by them. Once B-H bonds created by milling are attacked by $\mathrm{N}_{2} \mathrm{H}_{4}$ and $\mathrm{NH}_{3}$, $\mathrm{N}_{m} \mathrm{H}_{n}$ bonds are formed resulting in release of $\mathrm{AB}$ and an $\mathrm{N}_{m} \mathrm{H}_{n}$ coated surface. The sample mass may increase due to this substitution reaction. The coated $\mathrm{N}_{m} \mathrm{H}_{n}$ surface could be similar to $\mathrm{BN}-\mathrm{NH}_{x}$. The B-H bonds reacted with $\mathrm{NH}_{3}$ and $\mathrm{N}_{2} \mathrm{H}_{4}$ could be weak bond energy with $\mathrm{N}$ atom. Considering the main $\mathrm{B}-\mathrm{H}$ bond in $\mathrm{BNH}_{x}$ is $\mathrm{PAB}\left(\left\{\mathrm{BNH}_{2}\right\}_{n}\right)$, this weak $\mathrm{B}-\mathrm{H}$ bond could be $\mathrm{BH}_{2}$. A schematic depiction of this model is displayed in Figure 5 but the real reaction might be more complicated because the edge of $\mathrm{BNH}_{x}$ would have many kinds of structure. We need to identify "active" edge by the theoretical approach to clarify deeper reaction mechanism of this regeneration method. Further experimental work is also necessary to minimize or break the volume of $\mathrm{N}_{3} \mathrm{~B}_{3}$ ring structure and therefore increase the amount of $\mathrm{B}-\mathrm{H}$ bonds in the $\mathrm{BNH}_{x}$ by ball-milling (or other method). 


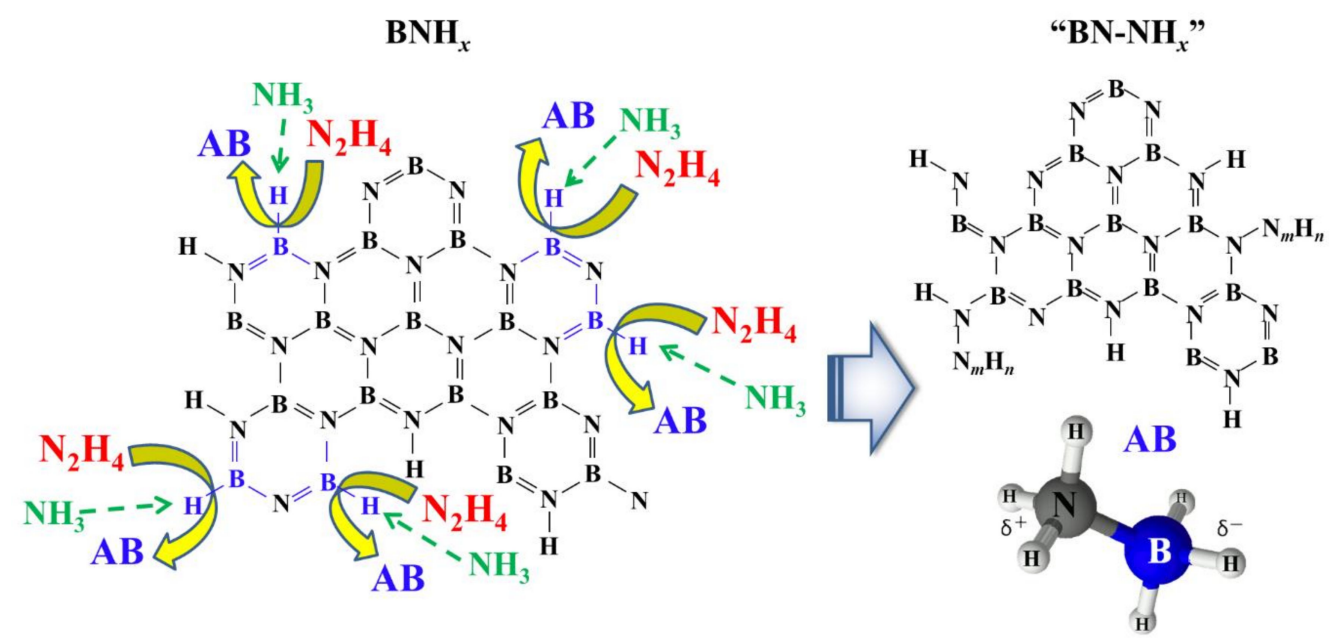

Figure 5. Conversion model of $\mathrm{AB}$ from $\mathrm{BNH}_{x}$ by the $\mathrm{N}_{2} \mathrm{H}_{4} / \mathrm{NH}_{3}$ treatment.

\section{Conclusions}

In this study, the synthesis of $\mathrm{AB}$ from $\mathrm{h}-\mathrm{BN}$ was successful using ball milling under hydrogen pressure and then soaked in $\mathrm{N}_{2} \mathrm{H}_{4}$-liquid $\mathrm{NH}_{3}$ solution. The THF-soluble product of this reaction was shown by ${ }^{11} \mathrm{~B} N M R$ to be $\mathrm{AB} . \mathrm{H}_{2} \mathrm{H}_{4} / \mathrm{NH}_{3}$ treated $\mathrm{BNH}_{x}$ which removed $\mathrm{AB}$, had similar RGA profile to $\mathrm{BN}-\mathrm{NH}_{x}$ below $500{ }^{\circ} \mathrm{C}$, indicating substitution of $\mathrm{N}-\mathrm{H}$ bonds for $\mathrm{B}-\mathrm{H}$ bonds proceeded. The key aspect of this chemistry is the creation of the defects by breaking $\mathrm{B}_{3} \mathrm{~N}_{3}$ ring at the surface of h-BN during the milling under $\mathrm{H}_{2}$. This phenomenon enables the formation of $\mathrm{B}-\mathrm{H}$ species that can be attacked by both $\mathrm{H}_{2} \mathrm{H}_{4}$ and $\mathrm{NH}_{3}$ to form $\mathrm{AB}$. These $\mathrm{B}-\mathrm{H}$ bonds in $\mathrm{BNH}_{x}$ would be low bond energy with $\mathrm{N}$ atom likewise broken $\mathrm{B}_{3} \mathrm{~N}_{3}$ ring structure, which can desorb hydrogen below $500{ }^{\circ} \mathrm{C}$. The presence of intermediates $\left(\mathrm{N}_{2} \mathrm{H}_{4} \mathrm{BH}_{3}\right.$ and $\left.\mathrm{B}\left(\mathrm{NH}_{2}\right)_{3}\right)$ in NMR indicates that their reaction routes could be the same as those of $\mathrm{PB}$ regeneration. Although this method is not commercially useful immediately, unless there is improvement of its low production yield (about $5 \%$ ), such surface chemistry could open up new possibilities of other thermodynamically tough chemical reactions. Of course, it may be possible to envision a hydrogen storage system using full hydrogen from $\mathrm{AB}\left(19.6\right.$ mass $\left.\% \mathrm{H}_{2}\right)$ if high $\mathrm{AB}$ yield of regeneration using our method is realized. If an effective method to break the strong bonding in $\mathrm{B}_{3} \mathrm{~N}_{3}$ ring and then create B-H bonding is found, this "one-pot regeneration" probably gives high yield of $\mathrm{AB}$.

Supplementary Materials: The following are available online at http://www.mdpi.com/1996-1073/13/21/5569/s1.

Author Contributions: Conceptualization, Y.K. and A.K.B.; methodology and investigation, T.N., H.U., and H.M.; writing —original draft preparation, T.N.; writing—review and editing, A.K.B., T.I., and B.L.D.; project administration, A.K.B., T.I. and Y.K.; funding acquisition, A.K.B., T.N., and Y.K. All authors have read and agreed to the published version of the manuscript.

Funding: This work was partially supported by University of the Ryukyus Research Project Promotion Grant for Young Researchers, NEDO under "Advanced Fundamental Research Project on Hydrogen Storage Materials", and U.S. Department of Energy, Office of Energy Efficiency and Renewable Energy for providing funding.

Acknowledgments: In this work, syntheses of $\mathrm{BNH}_{x}$ and $\mathrm{BN}-\mathrm{NH}_{x}$ were partially supported by Liang Zeng. The XRD measurement in LANL was operated by the support of Brian L. Scott.

Conflicts of Interest: The authors declare no conflict of interest.

\section{References}

1. Jacobson, M.Z. Review of solutions to global warming, air pollution, and energy security. Energy Environ. Sci. 2009, 2, 148-173. [CrossRef]

2. Abe, J.O.; Popoola, A.P.I.; Ajenifuja, E.; Popoola, O.M. Hydrogen energy, economy and storage: Review and recommendation. Int. J. Hydrogen Energy 2019, 44, 15072-15086. [CrossRef] 
3. Chen, P.; Zhu, M. Recent progress in hydrogen storage. Mater. Today 2008, 11, 36-43. [CrossRef]

4. Marder, T.B. Der Ammoniak-Boran-Komplex: Ein Automobiltreibstoff der Zukunft? Angew Chem. 2007, 119, 8262-8264. [CrossRef]

5. Baitalow, F.; Baumann, J.; Wolf, G.; Jaenicke-Rößler, K.; Leitner, G. Thermal decomposition of B-N-H compounds investigated by using combined thermoanalytical methods. Thermochim. Acta 2002, 391, 159-168. [CrossRef]

6. Demirci, U.B. Ammonia Borane: An Extensively Studied, Though Not Yet Implemented, Hydrogen Carrier. Energies 2020, 13, 3071(1)-3071(45). [CrossRef]

7. Esteruelas, M.A.; Nolis, P.; Oliván, M.; Oñate, E.; Vallribera, A.; Vélez, A. Ammonia borane dehydrogenation promoted by a pincer-square-planar rhodium(I) monohydride: A stepwise hydrogen transfer from the substrate to the catalyst. Inorg. Chem. 2016, 55, 7176-7181. [CrossRef]

8. Stephens, F.H.; Baker, R.T.; Matus, M.H.; Grant, D.J.; Dixon, D.A. Acid Initiation of ammonia-borane dehydrogenation for hydrogen storage. Angew. Chem. Int. Ed. 2007, 46, 746-749. [CrossRef]

9. Kang, X.D.; Fang, Z.Z.; Kong, L.L.; Cheng, H.M.; Yao, X.D.; Liu, G.Q.; Wang, P. Ammonia Borane Destabilized by Lithium Hydride: An Advanced On-Board Hydrogen Storage Material. Adv. Mater. 2008, 20, 2756-2759. [CrossRef]

10. Himmelberger, D.W.; Yoon, C.W.; Bluhm, M.E.; Carroll, P.J.; Sneddon, L.G. Base-Promoted ammonia borane hydrogen release. J. Am. Chem. Soc. 2009, 131, 14101-14110. [CrossRef]

11. Hilmmelberger, D.W.; Alden, L.R.; Bluhm, M.E.; Sneddon, L.G. Ammonia borane hydrogen release in ionic liquids. Inorg. Chem. 2009, 48, 9883-9889. [CrossRef]

12. Zhong, R.; Zou, R.; Nakagawa, T.; Janicke, M.T.; Semelsberger, T.A.; Burrell, A.K.; Del Sesto, R.E. Improved hydrogen release from ammonia-borane with ZIF-8. Inorg. Chem. 2012, 51, 2728-2730. [CrossRef]

13. Diyabalanage, H.W.K.; Shrestha, R.P.; Semelsberger, T.A.; Scott, B.L.; Bowden, M.E.; Davis, B.L.; Burrell, A.K. Cacium amidotrihydroborate: A hydrogen storage material. Angew. Chem. 2007, 119, 9153-9155. [CrossRef]

14. Fazen, P.J.; Remsen, E.E.; Beck, J.S.; Carroll, P.J.; McGhie, A.R.; Sneddon, L.G. Synthesis, properties, and ceramic conversion reactions of polyborazylene. A high-yield polymeric precursor to boron nitride. Chem. Mater. 1995, 7, 1942-1956. [CrossRef]

15. Davis, B.L.; Dixon, D.A.; Garner, E.B.; Gordon, J.C.; Matus, M.H.; Scott, B.L.; Stephens, F.H. Efficient regeneration of partially spent ammonia borane fuel. Angew. Chem. Int. Ed. 2009, 48, 6812-6816. [CrossRef]

16. Sutton, A.D.; Davis, B.L.; Bhattacharyya, K.X.; Ellis, B.D.; Gordon, J.C.; Power, P.P. Recycle of tin thiolate compounds relevant to ammonia-borane regeneration. Chem. Commun. 2010, 46, 148-149. [CrossRef] [PubMed]

17. Sutton, A.D.; Burrell, A.K.; Dixon, D.A.; Garner, E.B., III.; Gordon, J.K.; Nakagawa, T.; Ott, K.C.; Robinson, J.P.; Vasiliu, M. Regeneration of ammonia borane spent fuel by direct reaction with hydrazine and liquid ammonia. Science 2011, 331, 1426-1429. [CrossRef] [PubMed]

18. Davis, B.L.; Rekken, B.D.; Michalczyk, R.; Garner, E.B., III.; Dixon, D.A.; Kalviri, H.; Bakerd, R.T.; Thorne, D.L. Lewis base assisted B-H bond redistribution in borazine and polyborazylene. Chem. Commn. 2013, 80, 9095-9097. [CrossRef]

19. Tang, Z.; Chen, H.; Chen, X.; Wu, L.; Yu, X. Graphene oxide based recyclable dehydrogenation of ammonia borane within a hybrid nanostructure. J. Am. Chem. Soc. 2012, 134, 5464-5467. [CrossRef]

20. Reller, C.; Mertens, F. The recycling of spent ammonia borane with $\mathrm{HBr} / \mathrm{AlBr}_{3}$ and other $\mathrm{HX} / \mathrm{AlX}{ }_{3}$ based schemes. ChemPlusChem 2018, 83, 1013-1020. [CrossRef]

21. Qu, D.; Liss, K.-D.; Yan, K.; Reid, M.; Almer, J.D.; Wang, Y.-B.; Liao, X.; Shen, J. Gecko-foot-mimetic aligned single-walled carbon nanotube dry adhesives with unique electrical and thermal properties. Adv. Eng. Mater. 2011, 13, 17001221. [CrossRef]

22. Tang, Z.; Tan, Y.; Chen, X.; Yu, X. Regenerable hydrogen storage in lithium amidoborane. Chem. Commun. 2012, 48, 9296-9298. [CrossRef]

23. Wise, S.S.; Margrave, J.L.; Feder, H.M.; Hubbard, W.N. Fluorine bomb calorimetry. The enthalpy of formation of boron nitride. J. Phys. Chem. 1966, 70, 7-10. [CrossRef]

24. Matus, M.H.; Anderson, K.D.; Camaioni, D.M.; Autrey, S.T.; Dixon, D.A. Reliable predictions of the thermochemistry of boron-nitrogen hydrogen storage compounds: $\mathrm{B}_{\mathrm{x}} \mathrm{N}_{\mathrm{x}} \mathrm{H}_{\mathrm{y}}, \mathrm{x}=2,3$. J. Phys. Chem. A 2007, 111, 4411-4421. [CrossRef] 
25. Orimo, S.; Matsushita, T.; Fujii, H.; Majer, G. Hydrogen desorption property of mechanically prepared nanostryctured graphite. J. Appl. Phys. 2001, 90, 1545-1549. [CrossRef]

26. Miyaoka, H.; Ichikawa, T.; Fujii, H.; Kojima, Y. Hydrogen desorption reaction between hydrogen-containing fuctional groups and lithium hydride. J. Phys. Chem. C. 2010, 114, 8668-8674. [CrossRef]

Publisher's Note: MDPI stays neutral with regard to jurisdictional claims in published maps and institutional affiliations.

(C) 2020 by the authors. Licensee MDPI, Basel, Switzerland. This article is an open access article distributed under the terms and conditions of the Creative Commons Attribution (CC BY) license (http://creativecommons.org/licenses/by/4.0/). 